\title{
NUSHŪZ SUAMI-ISTRI DAN SOLUSINYA: Studi Tafsir al-Rāzī
}

\author{
Fatimah Zuhrah \\ IAIN Sumatera Utara \\ e-mail: fatimahzuhrah@yahoo.com
}

\begin{abstract}
Nushūz means a wife do anything against her husband for no reason that can be accepted by Islamic law (wife nushüz), or husband does not carry out its obligations as stipulated in Islamic law (husband nushūz). This article intends to analyze the concept of nushūz according to Islamic law in the perspective of Fakhr al-Dīn al- Rāzī in his Qur'anic commentary (tafsir ). It also discussed about the solutions of nushüz according to the Qur'an. Based on the study of sura al-Nisa verse: 34,35 , and 128 that nushüz can be done even by the wife or the husband. When problems of nushūz already potentially shiqāq, it is advisable to appoint a hakam (mediator), both from husband's families and wife's families.
\end{abstract}

\section{[}

Nushūz berarti seorang istri melakukan perbuatan yang menentang suami tanpa alasan yang dapat diterima oleh hukum Islam, atau sebaiknya suami tidak menjalankan kewajibannya sebagaimana ketentuan hukum Islam. Artikel ini bermaksud untuk menganalisis konsep nushūz menurut hukum Islam dalam perspektif Fakhr al-Dīn alRāzì dalam kitab tafsirnya. Selain itu juga dibahas tentang bagaimana tawaran solusi nushūz menurut al-Qur'an berdasarkan kajian terhadap surat al-Nisā' ayat 34, 35, dan 128 bahwa nushūz bisa dilakukan oleh istri maupun suami. Ketika permasalahan nushūz sudah mengkhawatirkan sehingga berpotensi shiqāq, maka dianjurkan untuk mengangkat seorang hakam (mediator), baik dari keluarga suami maupun keluarga istri.

Keywords: $\quad$ nushūz; suami; istri; Tafsìr al-Rāzī 


\section{Pendahuluan}

Term nushūz dalam literatur fikih lebih banyak ditujukan kepada istri dibanding suami. Ini dipahami karena ungkapan al-Qur'an surah al-Nisa' ayat 34 yang secara tegas menyebut kata nushūz untuk perempuan (istri). Sementara term nushūz adakalanya lahir dari istri, adakalanya lahir dari suami dan adakalanya lahir dari keduanya. Ayat-ayat tersebut di dalam QS. al-Nisa' ayat: 34, 35, dan 128 berdasarkan tafsirnya juga memberikan solusi konkret dalam menyelesaikan konflik rumah tangga antara suami dan istri.

Tihami mengatakan bahwa nushūz dalam perkawinan berarti seorang istri melakukan perbuatan yang menentang suami tanpa alasan yang dapat diterima oleh hukum Islam. Ia tidak menaati suaminya atau menolak diajak ke tempat tidurnya. ${ }^{1}$ Ketidakpatuhan istri dalam menjalankan kewajibannya, seperti tidak menempati rumah yang disediakan suami tanpa alasan yang pantas, meninggalkan rumah atau bepergian tanpa izin suami, melahirkan konsekuensi hukum bahwa istri dinilai nushūz. Ketentuan surat al-Nisa' ayat 34 tersebut mengisyaratkan bahwa suami harus memberi nasihat dengan baik istri yang nushūz, dan kalau ternyata istri tidak berubah, hendaklah suami berpisah ranjang. Jika istri masih terus dalam kondisi nushūz, maka suami boleh memukulnya dengan syarat tidak melukai badannya. ${ }^{2}$

Para mufassir berbeda pendapat dalam memahami dan menafsirkan nushūz dan solusi yang dilakukan oleh suami terhadap istri, dan oleh istri terhadap suami. Tulisan ini lebih lanjut akan melihat bagaimana Fakhr al-Dīn al-Rāzī dalam tafsirnya menjelaskan tentang solusi konflik nushūz yang dilakukan istri terhadap suami dan suami terhadap istri sebagaimana yang dimaksud oleh al-Qur'an.

\section{Biografi Fakhr al-Dīn al-Rāzī}

Fakhr al-Dīn al-Rāzī (544-606 H/1149-1209 M) memiliki nama lengkap Abū 'Abd Allāh Muhammad ibn “Umar ibn al-Ḥusayn ibn al-Hasan ibn 'Alī al-

${ }^{1}$ H.M.A. Tihami \& Sohari Sahrani, Fikih Munakahat(Jakarta: Rajawali Press, 2009), h. 185.

2Ibid., h. 186.

30 || Volume 26, Nomor 1, April 2016 
Tamāmī al-Bakrī al-Tibristān al-Rāzī. Ia dijuluki dengan gelar Fakhr al-Dīn alRāzì. ${ }^{3}$ Al-Rāzī lahir di Rayy sebuah wilayah di Persia, sekarang Iran pada tahun $544 \mathrm{H} / 1149$ M. Ada yang mengatakan ia lahir pada tahun $543 \mathrm{H}$. Sedikit diketahui tentang awal dari masa hidupnya namun banyak ahli sejarah sependapat bahwa ayahnya Diyā' al-Dīn, yang dikenal dengan Khätib al-Rayy (seorang orator ulung al-Rayy), adalah gurunya yang pertama dalam bidang kalam dan fikih. Setelah ayahnya wafat, dia belajar ilmu-ilmu keislaman dari Majd al-Dīn al-jillī dan belajar ilmu hukum (jurisprudensi) dari al-Kamāl alSamnānī. la banyak bertemu dengan ulama-ulama sezamannya.

Disebabkan pengetahuaannya yang luas, maka al-Rāzī mendapat berbagai gelar seperti: Khātib al-Rayy, al-Imām, Fakhr al-Dīn, dan Shaykh al-Islām. Dia mendapat julukan Khätib al-Rayy karena dia adalah ulama terkemuka Rayy. Dia dijuluki al-Imām karena menguasai ushul fikih dan syariat. Dia juga disebut Fakhr al-Dīn al-Rāzì karena penguasaannya yang sangat mendalam tentang berbagai disiplin keilmuan yang menyebabkannya berbeda dengan para tokoh pemikir dari Rayy. Dia juga dipanggil sebagai Shaykh al-Islām di Herat karena penguasaaan keilmuannya yang tinggi.

Al-Rāzī adalah seorang ulama yang ternama dan produktif pada masanya. Awalnya, Ia tertarik dengan bidang Kimia namun kemudian beliau banyak menulis dalam bidang tafsir, teologi, filsafat, hukum, obat-obatan, bahasa, fisika, sejarah, ilmu tentang bid'ah (heresiography), astronomi, logika, astrologi, and ilmu tentang firasat (physiognomy). Al-Rāzī menguasai bahasa Persia dan Arab dengan baik. Ia memiliki pemikiran yang cemerlang, kritis, dan ingatan yang kuat dan rasional. Ia tegas dalam memberikan analisis persoalan non-Muslim atau persoalan yang berhubungan dengan bid'ah. Karena keberanian pemikirannya al-Rāzī dimusuhi sebagian ulama yang bertentangan dengannya.

Perjalanan ilmiahnya ditandai dengan berkelana di negara-negara Muslim. Dia menuliskan perjalanannya dalam sebuah buku (Munāzaräāt Fakhr al-Dīn alRāzī fi Bilād Mā Warā'al-Nahr) yang ditulisnya sebanyak enam belas bagian. Di dalamnya direkam tempat-tempat yang ia kunjungi, para ulama yang ia temui,

\footnotetext{
${ }^{3}$ Mahmud Basuni Faudah, Tafsir-tafsir al-Qur'an: Perkenalan dengan Metodologi Tafsir (Bandung: Pustaka, 1987), h. 79.
} 
dan ringkasan diskusi yang ia lakukan bersama para ulama tersebut. Ia adalah seorang penganut mazhab Syāfi'ì dan aliran teologinya adalah Asy'ariyyah.

Murid al-Rāzī berdatangan dari seluruh penjuru wilayah Muslim. Menurut sebagian pendapat ketika al-Rāzī pindah dari satu tempat ke tempat lainnya paling sedikit 300 orang muridnya mengikutinya. Al-Rāzī kemudian menetap di Herat (sebuah wilayah yang berada di Afghanistan). Di sana al-Rāzī mengajar di sebuah madrasah yang sengaja dibangunkan untuknya. Suatu kali dalam sebuah kelas terbuka, terjadi diskusi yang berlangsung panas dan muncul perdebatan keras antara al-Rāzī dan Ibn al-Qudwa, seorang pemimpin Karramite. Akhirnya diskusi dan perdebatan ini menimbulkan banyak hujatan. Sepupu Sultan waktu itu menghujat al-Rāzī dengan kufr karena al-Rāzī membaca karya Ibn Sina dan Aristoteles. Masyarakat menjadi sangat marah pada waktu itu sehingga kehidupan al-Rāzī terancam. Al-Rāzī secara diam-diam dan hati-hati meninggalkan kota Herat. Tahun kepergiannya ini benar-benar berpengaruh pada kehidupan keilmuwan waktu itu sehingga para ulama menyebutnya dengan sanat al-fitnah (tahun fitnah).

Dalam setiap perdebatan, al-Rāzī mulai mendeskripsikan pemikirannya dan mendeskripsikan beragam alternatif bagi pemecahan masalahnya hingga akhirnya al-Rāzī secara ringkas menentukan pilihannya pada alternatif yang lebih disukai. Al-Rāzī menyimpulkan pandangan lawan-lawannya secara tepat dan menyeluruh. al-Rāzī tidak menjawab secara ringkas, al-Rāzī selalu memilih jawaban yang lengkap, panjang dan tidak mengulang pendapatnya.

Tuduhan yang paling utama yang ditujukan kepadanya adalah kepercayaannya terhadap ilmu sihir. Karyanya yang berjudul al-Sirr al-Maktūm fi Mukhātabāt al-Nujūm dianggap berisi tentang sihir. Padahal Ma'sumi mengatakan bahwa isi buku tersebut tidak menjustifikasi pandangan tentang sihir dan jelas sekali di dalamnya al-Rāzī mengakui bahwa studi tentang astrologi adalah sebagai cabang dari ilmu pengetahuan. Tapi al-Rāzī sendiri tidak mempercayai astrologi. Al-Rāzī membedakan apa yang dibenarkan Islam dan apa yang tidak. ${ }^{4}$

\section{${ }^{4}$ Ibid.}


Al-Rāzī wafat di Herat pada 606 H/1209 M. Dalam karyanya Wașiyya, yang ia diktekan kepada seorang muridnya sebelum ia wafat, ia mengatakan bahwa ia belum cukup memberikan hal-hal yang bermanfaat dibandingkan hal-hal yang mudharat dalam tulisannya. Pengakuannya ini menunjukkan ketidakpuasannya berkenaan dengan filosofi dan teologi yang merujuk kepada pendekatan al-Qur'an demi melanjutkan kebenaran di atas filsafat. Al-Rāzī juga mengatakan bahwa intelektual manusia cukup berat dalam menghadapi persoalan yang kompleks.

Sebagai ulama yang menguasai banyak bidang ilmu al-Rāzī juga memiliki banyak karya dalam berbagai bidang ilmu. Dalam bidang filsafat: 1) al-Mabāhịth al-Mashriqiyyah fi 'Ilm al-Ilāhiyyah wa 'I-Ṭabi'ilyyah. Buku ini adalah salah satu buku penting dalam bidang filsafat dan ditulis sebelum tahun $1185 \mathrm{M}$; 2) Muhasșal Afkār al-Mutaqaddimīn wa 'I-Muta'akhkhirīn min al-'Ulamā' wa 'IHukāmā' wa 'l-Mutakallimīn ditulis sebelum tahun 1209 M. Karyanya dalam bidang Tafsir adalah al-Tafsïr al-Kabïr yang ditulis sebelum tahun 1239. Karyanya dalam bidang etika adalah Kitāb al-Nafs wa 'l-Rūh wa Sharh Quwā Huma, ditulis sebelum tahun 1209 M. Karyanya dalam bidang ushul fikih adalah: 1) al-Mahșūl fí 'Ilm al-Ușūl; 2) Nihāyat al-'Uqūl fi Dirāyat al-Ușūl. Karyanya dalam bidang teologi adalah al-Mutakallimin fi IIm al-Kalām. Karyanya dalam bidang ilmu mantiq/logika adalah Kitāb al-Manțiq al- Kabīr. Karyanya dalam bidang pengobatan adalah Sharh Kulliyyat al-Qanūn fi ' I-Tibb. ${ }^{5}$

\section{Tafsīr al-Kabīr al-Rāzī}

Nama asli kitab tafsir al-Rāzī adalah Mafātiḥ al-Ghayb. Ia dikenal juga dengan nama Tafsìr al-Kabìr. Penyebutan kitab ini dengan nama Tafsìr al-Rāzì adalah menggunakan nisbah nama pengarangnya, sehingga nama Tafsir alRāzī sama terkenalnya dengan penyebutan Tafsìr al-Kabīr dan Mafätih alGhayb. ${ }^{6}$ Kitab tafsir 30 juz al-Qur'an ini disusun dalam 11 juz (buku). Metode penafsirannya adalah penafsiran ayat per ayat dari surat yang dibahas secara berurutan (mușhafi).

5Al-Dawūdī, Tabaqāt al-Mufassirinn (Beirut: Dār 'Ilmiyyah, tth.), h. 73.

${ }^{6}$ Abū al-Yaqẓan, Dirāsāt fi I-Tafsīr wa Rijālih (t.tp:tnp, t.th.), h. 118. 
Sistematika (tartib) tafsir ini terdiri dari delapan jilid besar. Tafsir ini banyak beredar di kalangan ahli ilmu pengetahuan. Sistematika Tafsir al-Rāzī adalah sistematika mușhafi di mana penafsiran dimulai dari surat al-Fatihah dan diakhiri dengan surat al-Nās. Tidak diketahui secara pasti apakah al-Rāzī menulis tafsirnya hingga selesai sebanyak 30 Juz. Pendapat yang berkembang mengatakan bahwa al-Rāzī menulis hanya sampai pada surat al-Anbiya'7 sedangkan selebihnya ditulis oleh muridnya. Ibn Ḥajar al-'Asqalānī mengatakan bahwa orang yang menyelesaikan Tafsìr al-Rāzī adalah Aḥmad bin Muhammad Abī al-Ḥazm." Pengarang Kashf al-Ẓunūn mengatakan bahwa yang menyelesaikan Tafsìr al-Rāzī adalah Shaykh Najm al-Dīn Aḥmad ibn Muḥammad al-Qamūlī dan Qāḍī al-Quḍāh Shihāb al-Dīn Ibn Khalīl. Merekalah yang telah menyempurnakan apa yang kurang dari kitab tersebut.8 Tampaknya ulama sepakat bahwa al-Rāzī tidak sempat menyelesaikan tafsirnya, namun menarik sekali bahwa kita menemukan keserasian metode dan alur pembahasaannya dalam penulisan dan penyajian dari awal hingga akhir kitab. ${ }^{9}$

Manhaj atau metode penafsiran yang ditempuh oleh al-Rāzī adalah metode taḥlīlī. Sebagaimana al-Qurțubī, al-Rāzī juga menjelaskan penafsiran ayat-ayat al-Qur'an secara menyeluruh dari kandungan yang ada di dalamnya. Ketika menjelaskan penafsiran suatu ayat, ia berupaya menjelaskan berbagai aspek dari ayat tersebut. Ia membahas bagian-bagian dari ayat yang ditafsirkan berdasarkan soal dan masalah yang cukup beragam. Ia menggunakan istilah yang bermacam-macam untuk pembahasan yang dilakukannya, misalnya ia menggunakan istilah al-bahth, al-su'āl, dan al-mas'alah. Hanya saja penjelasan yang dikemukakan lebih cenderung kepada filsafat, teologi, ilmu pengetahuan alam (eksakta).

Adapun ciri khas metode Tafsīr al-Rāzī yaitu: Pertama, pengarangnya berbicara panjang lebar dalam memberikan argumentasi. Penjelasannya yang panjang lebar mengesankan bahwa kitab tafsir ini seperti kitab filsafat atau

\footnotetext{
7Muhammad Ḥusayn al-Dhahabī, al-Tafsìr wa 7-Mufasirūn, juz I (Beirut: Dār al-Ihyā̄' al-Turāth al‘Arabī, t.th.),h. 293.

8Ibid.

${ }^{9}$ Mahmud Basuni Faudah, Tafsir-tafsir al-Qur'an..., h. 80.
} 
kitab matematika, atau kitab ilmu pengetahuan alam. Melihat penjelasan yang demikian panjang lebar, Ibn 'Ațiyah berkomentar bahwa di dalam Tafsìr alRāzī segalanya ada kecuali tafsir itu sendiri. Kedua, al-Rāzī mengutip pendapat dan pandangan ulama lain, kemudian ia membuat argumentasi terhadap pendapat yang dikutipnya. Ia membongkar kelemahan pendapat yang dikutipnya, walaupun bantahannya terkadang kurang memadai dan memuaskan. Ketiga, dalam penafsiran ayat-ayat yang memuat hukum ia mengangkat pendapat-pendapat mazhab fikih dan cenderung menjelaskan ayat-ayat yang ditafsirkannya untuk menguatkan mazhab Syafi'i karena ia bermazhab Syafi'i.

Tafsìr al-Rāzì memiliki corak atau lawn bi al-Ra'yi bahkan kitab ini dianggap sebagai salah satu tafsir bi al-ra'yi yang paling komprehensif. ${ }^{10}$ Tafsir ini dimasukkan kepada kategori bi al-ra'yi karena dalam menjelaskan ayatayat al-Qur'an, tafsïr ini menggunakan metode penalaran logika. Tafsir ini disebut juga dengan tafsir falsafi, yaitu tafsir yang dalam penjelasannya menggunakan pendekatan filsafat, termasuk dalam hal ini adalah tafsir yang bercorak kajian ilmu Kalam.

Selain menggunakan penalaran logika, tafsir ini dalam pembahasan ayatayat banyak menghubungkan dengan ilmu Kalam. Pembahasannya banyak memuat persoalan yang berhubungan dengan Allah dan eksistensi-Nya, alam semesta, dan manusia. Bidang-bidang lain yang masuk dalam pembahasan tafsir ini adalah ilmu pengetahuan alam, astronomi, perbintangan (zodiac), langit dan bumi, hewan dan tumbuhan dan bagian tubuh manusia. Pembahasan tentang filsafat dan penjelasan tentang tata bahasa (gramatika) secara panjang lebar juga mewarnai tafsirnya.

Karena luasnya pembahasan dalam Tafsìr al-Rāzī khususnya dalam bidang ilmu Kalam dan Ilmu Pengetahuan Alam, maka sebagian ulama menyebut tafsir ini sebagai 'ensiklopedi akademis' dalam bidang ilmu Kalam (teologi) dan Ilmu Pengetahuan Alam. ${ }^{11}$ Dari warna dan corak penafsiran dari Tafsìr al-Rāzì dapat kita simpulkan bahwa latar belakang keilmuan pengarangnya sangat memengaruhi penafsiran ayat-ayat al-Qur'an yang dijelaskannya.

${ }^{10}$ Abū al-Yaqzan, Dirāsāt fi I-Tafsīr wa Rijālih, h. 120.

11Muhammad Ḥusayn al-Dhahabī, Al-Tafsìr wa I-Mufasirūn, h. 295. 


\section{Nushūz dalam Perspektif al-Qur'an}

Al-Nushūz berasal dari al-nashz, yaitu tempat yang tinggi. Menurut istilah, adalah kedurhakaan istri kepada suaminya dalam hal-hal yang Allah wajibkan atasnya untuk mentaatinya. Menurut bahasa nushūz adalah masdar atau infinitive dari kata, نشز ينشز yang mempunyai arti tanah yang terangkat tinggi

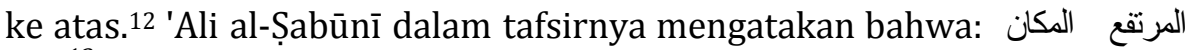
ما ارتفع من الأرض : Sedangkan menurut al-Qurtubī, nushūz adalah: النشز (suatu yang terangkat ke atas dari bumi). ${ }^{14}$ Adapun Ahmad Warson alMunawwir memberi arti nushūz dengan arti sesuatu yang menonjol di dalam, atau dari suatu tempatnya. Dan jika konteksnya dikaitkan dengan hubungan suami-istri maka ia mengartikan sebagai sikap istri yang durhaka, menentang dan membenci kepada suaminya. 15

Secara terminologis, nushūz mempunyai beberapa pengertian. Diantaranya, menurut fuqaha Hanafiyah, sebagaimana dikemukakan Saleh Ganim, adalah ketidaksenangan yang terjadi diantara suami-istri. Ulama mazhab Maliki berpendapat bahwa nushūz adalah saling menganiaya antara suami dan istri. Sedangkan menurut ulama Syafi'iyah, nushūz adalah perselisihan diantara suami-istri. Sementara itu ulama Hambaliyah mendefinisikanya dengan ketidaksenangan dari pihak istri atau suami yang disertai dengan pergaulan yang tidak harmonis. ${ }^{16}$

Menurut Ibnu Mansur, secara terminologis nushūz ialah rasa kebencian suami terhadap istri atau sebaliknya. Sedangkan menurut Wahbah al-Zuhaylī, guru besar ilmu fikih dan ushul fikih pada Universitas Damaskus, mengartikan nushūz sebagai ketidakpatuhan atau kebencian suami kepada istri terhadap apa yang seharusnya dipatuhi, begitu pun sebaliknya.

\footnotetext{
12Ibn Manzūr, Lisān al-'Arab (Beirut: Dār al-Ma'ārif, 1981), h. 637.

13Muhammad 'Alī al-Ṣābūnī, Rawāii' al-Bayān, Tafsìr Āyāt al-Ahkām min al-Qur'ān, juz I (Jakarta: Dār al-Kutub al-Islāmiyyah, 2001), h. 322.

14Al-Qurțubī,Jāmi' al-Aḥkām al-Qur'ān, juz III (Mesir: Dār al-Kitāb al-'Arabī, 1967), h. 170.

15Achmad Warson Munawwir, al-Munawwir (Yogyakarta: Pustaka Progresif, 1997), h. 1418.

${ }^{16}$ Saleh bin Ganim al-Saldani, Nushūz, alih bahasa A. Syauqi Qadri, cet. VI (Jakarta: Gema Insani Press, 2004), h. 25-26.
} 
Namun sebagian ulama berpendapat bahwa nushūz tidak sama dengan shiqāq, karena nushūz dilakukan oleh salah satu pasangan dari suami-istri. Nushūz berawal dari salah satu pihak, baik dari istri maupun suami, bukan kedua-duanya secara bersama-sama, karena hal tersebut bukan lagi merupakan nushūz melainkan dikategorikan sebagai shiqāq.17

Begitu pula mereka membedakan antara nushūz dan i'raḍ.18 Pengertian kata nushūz lebih menyeluruh dari pada kata i'raḍ. Hal ini tentu saja dikarenakan kandungan arti kata nushūz melingkupi seluruh jenis perlakuan buruk dari suami dan istri dalam hidup rumah tangga. Sedangkan i'rad hanya sebatas beralihnya perhatian suami dari istrinya kepada sesuatu yang lain.

Dari pengertian di atas, ternyata para ulama memiliki pandangan yang tidak jauh berbeda antara satu dengan yang lainya. Kesimpulannya, disamping perbuatan nushūz selain mungkin saja dilakukan oleh seorang istri, juga mungkin bila dilakukan oleh seorang suami, yakni jika suami tidak mempergauli istrinya dengan baik atau ia melakukan tindakan-tindakan yang melebihi batas-batas hak dan kewenangannya dalam memperlakukan istri yang nushūz sebagaimana yang digariskan oleh ajaran agama.

\section{Tafsir al-Rāzī tentang Solusi Konflik Nushūz Suami dan Istri}

Al-Rāzī menggunakan beberapa ayat dalam al-Qur'an sebagai pendekatan dalam menyikapi konflik suami-istri karena nushūz. Berdasarkan ayat-ayat tersebut, yaitu surat al-Nisa: 34,35 , dan 128, setidaknya terdapat tiga ketentuan al-Qur'an terhadap nushūz, yaitu:

1. Perlakuan suami terhadap istri yang nushūz. Ketentuan ini dinyatakan dalam surat al-Nisa': 34 sebagai berikut:

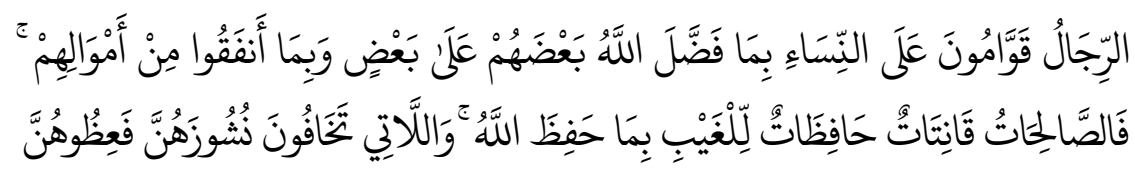

\footnotetext{
${ }^{17}$ Ibid., h. 1355.
}

${ }^{18}$ I'rad ialah kurangnya perhatian seorang suami terhadap istrinya hingga tidak ada komunikasi dan interaksi yang wajar sebagai pasangan hidup. Atau menelantarkan istri tanpa status, diperhatikan tidak, dicerai pun tidak. 


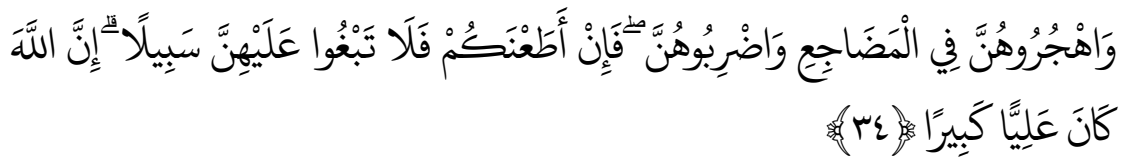

"Kaum laki-laki itu adalah pemimpin bagi kaum wanita, oleh karena Allah telah melebihkan sebahagian mereka (laki-laki) atas sebahagian yang lain (wanita), dan karena mereka (laki-laki) telah menafkahkan sebagian dari harta mereka. Sebab itu maka wanita yang saleh, ialah yang taat kepada Allah lagi memelihara diri ketika suaminya tidak ada, oleh karena Allah telah memelihara (mereka). Wanita-wanita yang kamu khawatirkan nushūznya, maka nasihatilah mereka dan pisahkanlah mereka di tempat tidur mereka, dan pukullah mereka. Kemudian jika mereka mentaatimu, maka janganlah kamu mencari-cari jalan untuk menyusahkannya. Sesungguhnya Allah Maha Tinggi lagi Maha Besar."

Setelah Allah menyebutkan wanita yang salehah dalam firman-Nya:

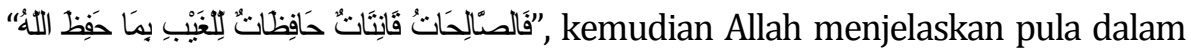

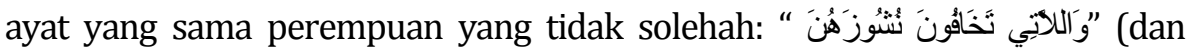
perempuan-perempuan yang kalian khawatirkan akan nushūz). Khawatir disini adalah keadaan takut dalam hati ketika menyangka suatu peristiwa yang dibenci pada masa yang akan datang terjadi. Imam Syafi'i berpendapat bahwa nushūz dapat berupa perkataan, dapat pula perbuatan. Berupa perkataan misalnya tidak menyahut apabila suami memanggilnya, meninggikan suara ketika berbicara apabila suaminya menasihatinya, kemudian berubah sikapnya. Berupa perbuatan misalnya hendaknya istri itu melayani apabila suaminya mendatanginya atau bersegera kepada urusan suaminya, bersegera menemani suaminya tidur dengan gembira apabila suaminya menyentuhnya. Apabila istri itu berubah melakukan demikian maka hal ini menunjukkan nushūz. Nushūz adalah bermaksiyat kepada suami. ${ }^{19}$

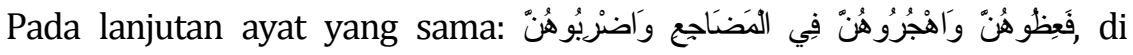
dalamnya ada beberapa permasalahan: Pertama, menurut Imam Syafi'i, suami dianjurkan menasihati istrinya dengan perkataan: "bertakwalah kepada Allah sesungguhnya bagiku ada hak bagi dirimu dan kembalilah kepada hal yang semula dan ketahuilah ta'at kepadaku itu wajib atasmu". Dalam hal ini suami tidak boleh memukul istinya, dengan harapan nasihat itu cukup baginya.

19Fakhr al-Dīn al-Rāzī, al-Tafsìr al-Kabīr, juzV (Beirut: Dār al-Kutub al-'Ilmiyyah, 1990), h. 72-74. 
Namun apabila ia (istri) menjadi nushūz maka pisahkan tempat tidurnya dan tidak berbicara dengannya. Menurut Imam Syafi'i, tidak berbicara dengan istri yang sedang pisah ranjang tidak lebih dari tiga hari. Dengan cara pisah ranjang, seorang istri yang mencintai suaminya akan meninggalkan nushūznya (akan berubah). Sebaliknya, bila istri tidak mencintai suaminya ia akan tetap pada nushūznya dan hal itu menunjukkan ia benar-benar nushūz. Sebagian ulama berpendapat bahwa pisah ranjang adalah menjauhkan dirinya dari hubungan suami istri.

Kemudian bila ia tetap nushūz maka boleh memukulnya. Imam Syafi'i mengatakan bahwa memukulnya boleh tetapi meninggalkannya (tidak memukulnya) lebih utama. Jika memukul, maka tidak sampai melukai, apalagi memukul hingga menyebabkan kebinasaan. Pemukulan dilakukan di tempat yang berbeda-beda dari badan, dan menjauhi memukul di muka. Terkait dengan jumlah, pemukulan tidak boleh lebih dari empat puluh kali. Sebagian ulama Syafi'iyah berpendapat bahwa pemukulan tidak lebih dari dua puluh kali. Pemukulan dilakukan dengan sapu tangan atau dengan tangannya, tidak menggunakan cambuk, juga tidak menggunakan tongkat. Intinya, dalam pemukulan ini hendaklah dengna cara yang paling ringan..$^{20}$

Kedua, bahwa para ulama berbeda pendapat tentang urutan perlakuan suami terhdapp istri yang nushūz. Sebagian berpendapat bahwa dalam ayat ini Allah mensyari'atkan sesuai dengan tertibnya. Walaupun secara zahir lafalnya menunjukkan secara bersama-sama namun secara implisit menunjukkan tertib dalam solusi. Ali bin Abi Țalib r.a. mengatakan: "nasihati dengan katakata, kalau masih membangkang pisahkan tempat tidurnya, kalau masih membangkang pukul dia, kalau pukulan tidak merubahnya kirim dua hakam. Sebagian ulama berpendapat bahwa ketika dikhawatirkan istri nushūz, maka diharuskan tertib. Namun jika memang diyakini sudah ada nushūz, maka dibolehkan untuk mengumpulkan solusi tersebut. Sebagian yang lain berpendapat, jika suami mengkhawatirkan terjadi nushūz, maka suami menasihati. Bolehkah suami memisahkan tidurnya? Ada kemungkinan bahwa

20 Ibid. 
pada masa awal terjadi nushūz, suami terlebih dahulu menasihatinya atau langsung memisahkan tempat tidurnya atau langsung memukulnya. ${ }^{21}$

2. Hakam sebagai mediator penyelesaian perkara nushūz. Hal ini dinyatakan dalam surat al-Nisa': 35 sebagai berikut:

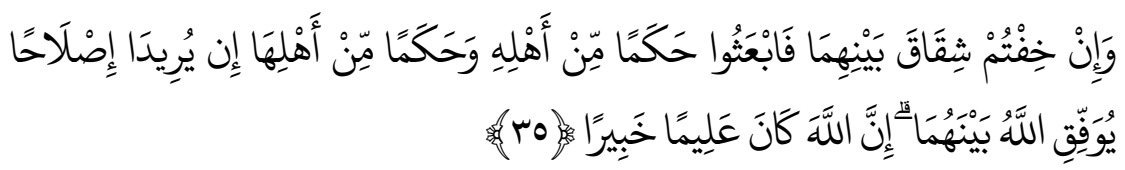

"Dan jika kamu khawatirkan ada persengketaan antara keduanya, maka kirimlah seorang hakam dari keluarga laki-laki dan seorang hakam dari keluarga perempuan. Jika kedua orang hakam itu bermaksud mengadakan perbaikan, niscaya Allah memberi taufik kepada suami-istri itu. Sesungguhnya Allah Maha Mengetahui lagi Maha Mengenal."

Beberapa tafsir penting dari ayat ini adalah: Pertama, menurut Ibn 'Abbās, kata خهنم (kamu khawatir) berarti engkau telah mengetahui dan ini berbeda

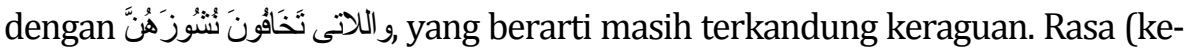
takutan) pada ayat di awal diatasi dengan nasihat kemudian pisah ranjang kemudian pukulan. Di sini sudah terlihat ciri-ciri istri yang nushūz, sehingga kekhawatiran disini memunculkan sebuah kepastian bahwa istri ini memang telah nushūz, lebih dari sekedar khawatir. Sebagian mufassir mengatakan bahwa ada shiqāq (konflik) telah diketahui sekalipun tidak pasti shiqāq ini berasal dari hal mana. Kebutuhan terhadap dua orang hakam menunjukkan kepada makna shiqāq (konflik) ini. Manfaat dari mengutus dua orang hakam bukanlah untuk menghilangkan shiqāq yang sudah ada tetapi untuk menghilangkan shiqāq pada masa yang akan datang. ${ }^{22}$

Kedua, para ulama berbeda pendapat tentang siapa yang dimaskud hakam? Ada yang berpendapat hakam adalah imam atau hakim. Ada yang berpendapat hakam adalah seseorang yang saleh dari golongannya, karena dalam kalimat kفإنْ خِفنم khitabnya adalah seluruh mukminin. Imam Syafi'i berpendapat bahwa yang disukai adalah mengutus dua orang yang adil dan menjadikan dia hakamnya. Yang lebih utama satu dari keluarga suami dan satu dari keluarga

${ }^{21}$ Ibid.

22 Ibid.

40 || Volume 26, Nomor 1, April 2016

AL-AHKAM p-ISSN: 0854-4603; e-ISSN: 2502-3209 
istri, karena keluarga lebih memahami keadaannya dari pada orang asing dan lebih menyukai/menghendaki islah (kebaikan). Namun apabila hakam itu orang asing boleh juga. Manfaat hakam ini adalah untuk membuka keadaan yang sebenarnya sebagai jalan untuk mengetahui apa yang dinginkan dan disukai bagi kedua pihak untuk langgengnya perkawinan mereka atau berpisahnya mereka. Kedua hakam ini berkumpul untuk bermusyawarah untuk memberikan keputusan yang lebih dekat dengan kebenaran. ${ }^{23}$

Ketiga, terkait asal terjadinya shiqāq antara suami istri, apakah berasal dari keduanya atau dari salah satunya antara suami dan istri. Jika dari istrinya maka berarti ia nushūz, dan telah dibahas hukumnya sebelumnya. Jika dari suaminya, seperti dia telah menikah secara halal dengan wanita lain, dan istrinya tahu hal itu mubah, maka ia dilarang shiqāq, sehingga ia menerimanya. Jika tidak menerima maka ia telah menjadi nushūz. Namun jika suami berbuat yang zalim, maka imam berhak mengutusnya untuk berbuat yang wajib. ${ }^{24}$

Keempat, apakah boleh kedua hakam menetapkan hukum atau ketetapan bagi suami istri tersebut tanpa izin mereka? Misalnya menetapkan talak bagi suami atau menetapkan khulu' dengan cara istri membayar dari harta? Imam Syafi'i, Malik, dan Ishaq berpendapat boleh. Sedangkan Abu Hanifah berpendapat tidak boleh. ${ }^{25}$

3. Ketentuan al-Qur'an terhadap suami yang nushūz, sebagaimana digambarkan dalam surat al-Nisa': 128 sebagai berikut:

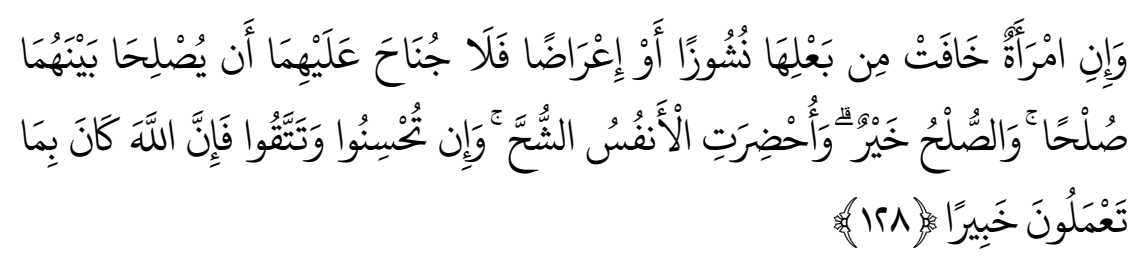

"Dan jika seorang wanita khawatir akan nushūz atau sikap tidak acuh dari suaminya, maka tidak mengapa bagi keduanya mengadakan perdamaian yang sebenar-benarnya, dan perdamaian itu lebih baik (bagi mereka) walaupun manusia itu menurut tabiatnya kikir. Dan jika kamu bergaul dengan istrimu

${ }^{23}$ Ibid.
24 Ibid.
25 Ibid.

AL-AHKAM

p-ISSN: 0854-4603; e-ISSN: 2502-3209

Volume 26, Nomor 1, April 2016 
secara baik dan memelihara dirimu (dari nushūz dan sikap tak acuh), maka sesungguhnya Allah Maha Mengetahui apa yang kamu kerjakan."

Ayat ini merupakan peringatan kepada para suami tentang kemungkinan terjadinya nushūz oleh suami. Di dalamnya terdapat beberapa pokok pembahasan. Pertama, kata takut berarti didasarkan pada pengetahuan. Orang lain berpendapat "ia menyangka", namun sesungguhnya ketakukan disini yaitu rasa khawatir itu sendiri yang muncul dengan adanya tanda-tanda yang dilakukan oleh suaminya. Semisal ketika seorang suami berkata kepada istrinya: "sesungguhnya engkau sudah tua dan aku ingin menikahi seorang gadis yang cantik." Nushūz artinya bencinya salah seorang pasangan kepada pasangan lainnya atau bagian tinggi dari tanah. Nushūz-nya suami pada istrinya adalah suami memalingkan wajahnya dari wajah istri, meninggalkan pergaulan dengan istrinya, dan menolak bercengkerama dengan istrinya.

Kedua, para mufassir menyebut sebab turunnya ayat ini dengan beberapa riwayat: a) Diriwayatkan dari Sa'īd bin Jubayr dari Ibn 'Abbās bahwa ayat ini turun berkenaan dengan kasus Ibn Abī Shayb yang mempunyai seorang istri dan mempunyai beberapa orang anak. Suatu ketika Shayb bermaksud mentalak istrinya itu. Kemudian istrinya berkata: "Jangan ceraikan aku dan biarkan aku demi kebaikan anak-anak dan beri sedikit saja dari bagian malamku dalam sebulan" Maka berkata suaminya jika demikian maka baiklah." b) Ayat ini diturunkan kepada Sawdah binti Zam'ah. Rasulullah ingin menceraikannya, namun Sawdah menolak dan mengatakan bahwa jatah giliran bermalamnya supaya diberikan kepada 'Aishah. Nabi setuju dan tidak jadi menceraikannya. c) Diriwayatkan dari 'Aishah, ia berkata bahwa ayat ini diturunkan kepada seorang perempuan yang memiliki suami dan suaminya ingin menggantikannya dengan orang lain kemudian ia berkata: "Jangan ceraikan aku dan menikahlah dengan yang lain, persoalan nafkah dan giliran adalah urusanmu, aku tidak meminta"

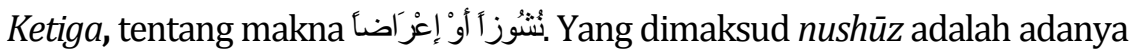
kekerasan pada perkataan, perbuatan, atau pada keduanya. Sedangkan yang dimaksud i'rad adalah diam dari berbuat baik atau buruk, mengajak atau menyakiti. I'rad menunjukkan atas kuatnya rasa benci.

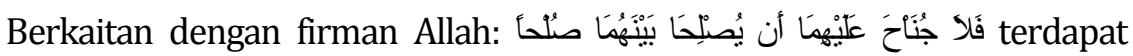
beberapa pokok penafsiran: Pertama, hak istri atas suami adalah mahar, 
nafkah atau jatah giliran (bermalam). Ketiga hal ini yang menjadi ketentuan bagi tuntutan istri dari suaminya baik ia (suami) menghendaki atau membangkang. Namun wathi' bukan merupakan tuntutan. Suami tidak boleh dipaksa untuk wathi'. Maka al-Rāzì berpendapat, perdamaian adalah ibarat sorang istri melepaskan hak maharnya seluruhnya atau sebagiannya kepada suaminya, atau menggugurkan hak nafkahnya, atau menggugurkan jatahnya (giliran malamnya). Hal itu agar suaminya tidak mentalaknya dan apabila masalahahnya demikian maka dibolehkan. Kedua, Allah menyebutkan ayat فلا

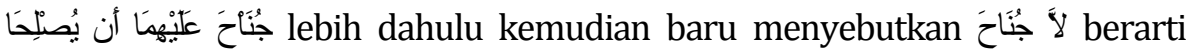
mengutamakan rukhșah, dan bertujuan untuk menghilangkan dosa. Maka Allah menjelaskan bahwa perdamaian adalah tidak berdosa dan di dalamnya terdapat kebaikan yang besar dan manfaat yang banyak. Apabila suami istri berdamai atas sesuatu maka hal itu baik dari pada berpisah atau tetap berوأحْضِرَت الأنفس الثَح : (walaupun pada dasarnya manusia itu kikir), bahwa shukh (bakhil) adalah hal yang biasa pada diri seseorang. Bakhil adalah sifat semua orang, sehingga mengandung kemungkinan makna bahwa sekalipun seorang istri kikir untuk melepas atas bagian dan haknya dan juga mengandung kemungkinan makna bahwa suami kikir karena lamanya tinggal dengan istrinya yang sudah tua dan sudah keriput wajahnya dan tidak ada lagi kelezatan dalam pergaulannya.

Zamakhsyari, penulis kitab tafsir al-Kashshāf mengatakan bahwa Imran bin Hațān al-Khārijī adalah seorang laki-laki yang berkulit hitam (sawo matang) yang memiliki istrinya seorang perempuan yang sangat cantik. Pada suatu hari istrinya memandangi suaminya kemudian berkata: "Alhamdulillah". Sang suami bertanya: "Ada apa? Istrinya menjawab; "Aku bersyukur kepada Allah atas halku dan halmu bahwa kita akan menjadi ahli surga. Sesungguhnya engkau telah diberi rizki seorang perempuan cantik seperti aku, dan engkau bersyukur. Sedangkan aku diberi rezeki laki-laki seperti engkau dan aku bersabar. Allah telah berjanji akan memberi surga kepada hamba-Nya yang bersyukur dan bersabar." 26

26Ibid,, h. 75 -76. 
Dalam tafsirnya, al-Rāzī memisahkan pengertian nushūz istri dan nushūz suami. Nushūz istri bisa dari perbuatan, perkataan, dan sikap. Sementara nushūz suami adalah keengganan suami terhadap istri dalam mempergauli dan menyakitinya. Ada beberapa solusi yang harus diambil dalam menghadapi nushūz istri. Pertama, menasihati istri itu, yaitu nasihat berdasarkan al-Qur'an berupa pergaulan yang baik kepada suami, dan pengakuan akan kedudukannya terhadap istri. Menasihati dapat dilakukan dengan kata-kata; "Bertakwalah kepada Allah, sesungguhnya bagiku ada hak bagi dirimu dan kembalilah kepada hal yang semula dan ketahuilah taat kepadaku itu wajib atasmu" Tidak boleh memukul dalam keadaan ini dengan harapan nasihat itu cukup baginya. Namun apabila ia menjadi nushūz maka pisahkan tempat tidurnya dan tidak berbicara dengannya. ${ }^{27}$

Kedua, yaitu memisahkan tempat tidur. Ketiga, memukul istri. Pukulan di sini adalah pukulan pendidikan bukan pukulan yang menyakitkan, tidak mematahkan tulang dan tidak menyebabkan luka seperti meninju dan yang semisalnya, karena tujuannya untuk memperbaiki, bukan yang lain. Istri yang nushūz antara lain karena memasukkan orang yang dibenci dan tidak disukai oleh suami mereka, meski bukan bermaksud berzina. Bila istri belum juga kembali taat setelah dipukul, maka dapat dikatakan bahwa istri telah berlaku shiqāq. Maka langkah berikutnya dalah mengutus juru damai atau hakam atau mediator. ${ }^{28}$

Jadi langkah-langkah yang harus ditempuh bila istri nushūz secara ringkas dapat disebutkan yaitu menasihati istri dulu, jika dia menerima maka itu yang diharapkan dan jika tidak menerima maka pisah ranjang, dan jika pisah ranjang tidak membuatnya jera maka pukullah dia, jika tidak berhasil maka seorang hakim mengirim juru damai (hakam) dari keluarga (perwakilan) suami dan istri. Kedua juru damai harus melihat dari segi maslahat dan mudarat, pada saat itu mungkin terjadi khulu'.29

\footnotetext{
${ }^{27}$ Ibid.

${ }^{28}$ Ibid.

${ }^{29} \mathrm{HR}$. al-Ṭabarī dalam Jāmi' al-Bayān (5/45) dari Saî̀ ibn Jubayr, meskipun ada sedikit perbedaan.
} 
Sementara nushūz yang dilakukan suami dalam pandangan al-Rāzī adalah sama maknanya dengan nushūz-nya istri, yaitu bencinya salah satu pasangan terhadap pasangannya. Nushūz suami misalnya ketika suami mengatakan kepada istrinya; "Sesungguhnya engkau sudah tua dan aku ingin menikahi seorang gadis yang cantik" Nushūz dari pihak suami ialah bersikap keras terhadap istrinya, tidak mau menggaulinya, dan tidak mau memberikan haknya. Menurut al-Rāzī hak istri atas suami adalah mahar, nafkah, atau jatah. Ketiga hal ini yang menjadi ketentuan bagi tuntutan istri dari suaminya baik ia (suami) menghendaki atau membangkang.

\section{Solusi Masalah Nushūz dalam Konteks Kekinian}

Permasalahan konflik nushūz suami dan istri, al-Rāzī dalam tafsirnya menyebutkan bahwa langkah-langkah dalam menyelesaikan konflik nushūz istri adalah: pertama, memberikan nasihat yakni dilakukan dengan mengingatkan istri atas kewajibannya dalam rumah tangganya, kedua, melakukan pisah ranjang dengannya, dan ketiga, mendidiknya dengan cara memukul istrinya. Kedua langkah yang disarankan oleh al-Rāzī, yakni langkah menasihati dengan mengingatkan istri atas kewajibannya dalam rumah tangga dan langkah berpisah ranjang dengannya bagi penulis belumlah solusi terbaik dalam menyelesaikan konflik nushūz suami dan istri. Apabila nasihat hanya dilakukan dengan mengingatkan pihak istri saja atas kewajibannya dalam rumah tangganya, tentu hal tersebut tidaklah berjalan efektif. Satu hal yang perlu diamati lebih mendalam adalah terkait dengan motif di balik nushūz istri. Kalau sikap pembangkangan yang dilakukan istri ternyata berasal dari perasaan tidak enak yang dirasakan oleh istri yang bersumber dari diri, sikap, dan respon suaminya, maka langkah yang tepat dalam mengangani nushūz seorang istri adalah dengan mengajak istrinya untuk berkomunikasi dan bermusyawarah dalam menyelesaikan masalah yang muncul dari sikap dan perilaku istrinya. Kemudian bagi suami juga seyogianya berusaha mencari penyebab perubahan sikap istrinya dan memperbaiki keadaan dengan meminimalisir bahkan menghilangkan hal-hal yang menjadi penyebab pembangkangan istrinya tersebut.

Selanjutnya pendapat al-Rāzī untuk meninggalkan istri di ranjangnya merupakan "pilihan" kepada suami untuk meninggalkan istri didorong oleh rasa 
tidak senang kepada sikapnya. Ini dipahami dari kata hajr, yang berarti meninggalkan tempat atau keadaan yang tidak baik atau tidak disenangi menuju ke tempat dan atau keadaan yang baik atau lebih baik. Berdasarkan hal ini Quraish Shihab menafsirkan kata hajr ini tidak hanya digunakan untuk sekedar meninggalkan sesuatu, tetapi di samping itu ia juga mengandung dua hal lain. Pertama, bahwa sesuatu yang ditinggalkan itu buruk atau tidak disenangi, dan yang kedua ia ditinggalkan untuk menuju tempat dan keadaan yang lebih baik. Artinya suami harus berusaha untuk meraih di balik pelaksanaan perintah itu sesuatu yang baik atau lebih baik dari keadaan semula. ${ }^{30}$

Mengenai pemukulan terhadap istri, pukulan di sini adalah pukulan yang bertujuan untuk mendidik, bukan pukulan yang menyakitkan. Mutawallī Sha'rawī menjelaskan bahwa yang dimaksud dengan memukul adalah pemukulan yang tidak sampai mengucurkan darah, tidak meninggalkan bekas, dan tidak meretakkan tulang. Pemukulan dilakukan dalam rangka menunjukkan rasa ketidakridaan suami atas perilaku istri, karena itu ia tidak boleh dilakukan atas dasar rasa kebenciaan, tapi justru dengan rasa kasih sayang yang dimaksudkan untuk merubah perilaku ketidaktaatan istri. ${ }^{31}$

Dalam konteks hukum di Indonesia nushūz dikaitkan dengan hak dan kewajiban yang harus dilaksanakan suami dan istri. Hukum Indonesia tidak mengatur nushūz suami, namun yang diatur hanya nushūz istri. Hal ini sebagaiamana dijelaskan dalam pasal 84 Kompilasi Hukum Islam sebagai berikut: 1) istri dapat dianggap nushūz jika ia tidak melaksanakan kewajibankewajibannya sebagaimana dimaksid dalam pasal 83 ayat (10 kecuali dengan alasan yang sah; ${ }^{32}$ 2) Selama istri dalam nusyuz, kewajiban suami terhadap istrinya tersebut pasal 80 ayat (4) huruf a dan b tidak berlaku kecuali hal-hal untuk kepentingan anaknya;33 3) Kewajiban suami tersebut pada ayat (2) di

\footnotetext{
30M. Quraish Shihab, Tafsir al-Misbah, volume 7 (Jakarta: Lentera Hati, 2002), h. 430.

${ }^{31}$ Mutawallī Sha'rawī, Tafsìr Sha'rawī (Medan: Duta Azhar, 2006), h. 43.

32Pasal 83 ayat (1) Kompilasi Hukum Islam menyebutkan bahwa "Kewajiban utama bagi seorang istri adalah berbakti lahir dan batin kepada suami di dalam batas-batas yang dibenarkan oleh hukum Islam.

${ }^{33}$ Sesuai ketentuan pasal 80 ayat (4) huruf a, maka istri yang nushūz tidak berhak mendapatkan Nafkah, kiswah dan tempat kediaman istri. Kemudian sesuai huruf b, maka istri yang nushüz tidak berhak mendapatkan biaya rumah tangga, biaya perawatan dan biaya pengobatan bagi istri.
} 
atas berlaku kembali setelah istri tidak nushūz; 4) Ketentuan tentang ada atau tidaknya nushūz dari istri harus didasarkan atas bukti yang sah.

Ketentuan nushūz dalam hukum di Indonesia, yang hanya diberlakukan bagi istri nampaknya kurang adil, karena istri diberi hukuman dengan tidak mendapatkan nafkah, kiswah (pakaian), tempat tinggal, biaya rumah tangga, biaya perawatan dan biaya pengobatan. Sementara karena tidak ada ketentuan nushūz suami, maka diidentikkan dengan pelanggaran ta'lik talak, yakni suami tidak melaksanakan kewajibannya atau melakukan pelanggaran terhadap ta'lik talak ${ }^{34}$ yang dibacakannya setelah akad nikah. Maka bagi istri yang tidak menerima suaminya melakukan pelanggaran ta'lik talak, dapat mengajukan perceraian dengan cara gugat cerai.

\section{Kesimpulan}

Secara terminologis nushūz ialah rasa kebencian suami terhadap istri atau sebaliknya. Nushūz dapat berupa perkataan maupun perbuatan. Nushūz istri adalah pembangkangan kepada suami dan tidak menurut padanya. Sementara nushūz yang dilakukan suami adalah sama maknanya dengan nushūz-nya istri yaitu bencinya salah satu pasangan terhadap pasangannya.

Ada beberapa solusi yang harus diambil dalam menghadapi nushūz istri menurut al-Rāzī, pertama, menasihati istri dengan nasihat yang dianjurkan alQur'an berupa pergaulan yang baik kepada suami, dan pengakuan terhadap kedudukan masing-masing suami-istri. Nasihat dilakukan dengan kata-kata yang baik. Kedua, berpisah tempat tidur dengan istri untuk memberi kesempatan kepada masing-masing suami-istri melakukan introspeksi. Ketiga, memukul istri sebagai salah satu metode dalam mendidik istri. Pukulan disini adalah pukulan pendidikan, bukan pukulan yang menyakitkan, tidak mematahkan tulang dan tidak menyebabkan luka seperti meninju dan yang se-

\footnotetext{
${ }^{34}$ Adapun isi dari sighat takik talak adalah sebagai berikut "Sewaktu-waktu saya: 1. Meninggalkan istri saya tersebut dua tahun berturut-turut; 2 . Atau saya tiada memberikan nafkah wajib kepadanya tiga bulan lamanya; 3. Atau saya menyakiti badan/jasmani istri saya itu; 4. Atau saya membiarkan (tidak memperdulikan) istri saya itu enam bulan lamanya, Kemudian istri saya tidak ridho dan mengadukan halnya kepada Pengadilan Agama, dan pengaduannya dibenarkan serta diterima oleh pengadilan tersebut, dan istri saya itu membayar uang sebesar Rp. 10.000,- (sepuluh ribu rupiah) sebagai iwad (pengganti) kepada saya, maka jatuhlah talak saya satu kepadanya.
} 
misalnya, karena tujuannya untuk memperbaiki keadaan. Sementara solusi yang ditawarkan manakala suami nushüz adalah istri lebih baik kalau memaafkan suami dengan cara menerima sebagian hak yang tidak diberikan suami kepadanya demi menjaga hubungan suami istri agar kembali harmonis.[a]

\section{DAFTAR PUSTAKA}

Abū al-Yaqụan, Dirāsātfi I-Tafsīr wa Rijālih, t.t.p: t. p, t.th. al-Dawūdī, Tabaqāt al-Mufassirīn, Beirut: Dār al-'Ilmiyyah, t.th.

al-Dhahabī, Muhammad Husayn, al-Tafsīr wa I-Mufassirūn, juz I, Beirut: Dār alIhyā' al-Turāth al-'Arabī, t.th.

Faudah, Mahmud Basuni, Tafsir-tafsir al-Qur'an: Perkenalan dengan Metodologi Tafsir, Bandung: Pustaka, 1987.

Ibn Manzūr, Lisān al-'Arab, Beirut: Dār al-Ma’ārif, 1981.

Munawwir, Achmad Warson, al-Munawwir, Yogyakarta: Pustaka Progresif, 1997.

al-Qurțubī, Jāmi' al-Ahkām al-Qur'ān, juz III, Mesir: Dār al-Kitāb al-'Arabī, 1967.

al-Rāzī, Fakhr al-Dīn, al-Tafsìr al-Kabìr, juz V, Beirut: Dār al-Kutub al-'Ilmiyyah, 1990.

al-Ṣābūnī, Muhammad 'Alī, Rawāi' al-Bayān, Tafsìr Āyāt al-Ahkām min alQur'ān, juz I, Jakarta: Dār al-Kutub al-Islāmiyyah, 2001.

al-Saldani, Saleh bin Ganim, Nushuz, alih bahasa A. Syauqi Qadri, cet. VI, Jakarta: Gema Insani Press, 2004.

Kompilasi Hukum Islam.

Sanusi, Nur Taufiq, Fikih Rumah Tangga Perspektif Al-Qur'an dalam Mengelola Konflik Menjadi Harmoni, Tangerang: eLSAS, 2011.

Sha'rawī, Mutawallī, Tafsìr Sha'rawī, Medan: Duta Azhar, 2006.

Shihab, M. Quraish, Tafsir al-Misbah, Volume 7, Jakarta: Lentera Hati, 2002.

al-Ṭabarī, Abū Ja'far Muhammad ibn Jarīr, Jāmi' al-Bayān 'an Ta'wīl al-Qur'ān, Beirut: Dār al-Fikr, 1988.

Tihami, H.M.A., \& Sohari Sahrani, Fikih Munakahat, Jakarta: Rajawali Press, 2009.

'Umar, Nasaruddin, Argumen Kesetaraan Jender Perspektif al-Qur'an, Jakarta: Paramadina, 1999. 